\title{
Victim and villain: ambiguous experience of nursing students in the university context
}

\author{
Vítima e vilã: experiência ambígua de estudantes de \\ enfermagem no contexto universitário \\ Víctima y villana: experiencia ambigua de estudiantes \\ de enfermería en el contexto universitario

\section{Luma Costa Pereira Peixoto ${ }^{a}$ \\ Evangelia Kotzias Atherino dos Santos ${ }^{b}$ Luana Machado Andrade ${ }^{a}$ Patrícia Anjos Lima de Carvalho ${ }^{a}$ Edite Lago da Silva Sena ${ }^{a}$}

How to cite this article: Peixoto LCP, Santos EKA, Andrade LM, Carvalho PAL, Sena ELS. Victim and villain: ambiguous experience of nursing students in the university context. Rev Gaúcha Enferm. 2021;42:e20200365. doi: https://doi.org/10.1590/19831447.2021.20200365
- Universidade Estadual do Sudoeste da Bahia (UESB), Departamento de Saúde II, Programa de Pós-graduação em Enfermagem e Saúde. Jequié, Bahia, Brasil.

b Universidade Federal de Santa Catarina (UFSC) Programa de Pós-graduaçăo em Enfermagem. Florianópolis, Santa Catarina, Brasil.

\section{ABSTRACT \\ Objective: To understand how Undergraduate Nursing Students signify the university context.}

Method: A qualitative research, of a phenomenological nature, based on the ontology of Maurice Merleau-Ponty, with the participation of 41 undergraduate nursing students from a public university in the interior of Bahia, Brazil. Data were collected from February to April 2019, using four wheels of Community Therapy, whose produced material was submitted to the Analytical of Ambiguity technique.

Results: From the analysis of the experiential descriptions, two categories emerged that reveal the significance attributed by students to their experiences in the university context: the university that generates suffering and the university that provides growth.

Final considerations: Undergraduate Nursing students signify the university context as an ambiguous experience, at the same time that the university is seen as generating suffering, it is also seen as capable of providing intellectual, sociocultural, affective and political growth

Keywords: Students, nursing. Mental health. Universities

\section{RESUMO}

Objetivo: Compreender como os Estudantes de Graduação em Enfermagem significam o contexto universitário

Método: Pesquisa de abordagem qualitativa, de natureza fenomenológica, fundamentada na ontologia de Maurice Merleau-Ponty, com participação de 41 estudantes de Graduação em Enfermagem de uma universidade pública do interior da Bahia, Brasil. Os dados foram coletados no período de fevereiro a abril de 2019, por meio de quatro rodas de Terapia Comunitária, cujo material produzido foi submetido à técnica Analítica da Ambiguidade.

Resultados: Da análise das descrições vivenciais emergiram duas categorias que revelam o significado atribuído pelos estudantes às suas vivências no contexto universitário: a universidade que gera sofrimento e a universidade que proporciona crescimento.

Considerações finais: Os estudantes de Graduação em Enfermagem significam o contexto universitário como uma experiência ambígua, ao mesmo tempo em que a universidade é apontada como geradora de sofrimento, ela é vista, também, como capaz de proporcionar crescimento intelectual, sociocultural, afetivo e político.

Palavras-chave: Estudantes de enfermagem. Saúde mental. Universidades.

\section{RESUMEN}

Objetivo: Comprender cómo los estudiantes de Grado en Enfermería entienden el contexto universitario

Método: Investigación cualitativa, de carácter fenomenológico, basada en la ontología de Maurice Merleau-Ponty, con la participación de 41 estudiantes de pregrado en enfermería de una universidad pública del interior de Bahía, Brasil. Los datos se recolectaron de febrero a abril de 2019, utilizando cuatro ruedas de Terapia Comunitaria, cuyo material producido fue sometido a la técnica de Análisis de Ambigüedad.

Resultados: Del análisis de las descripciones vivenciales surgieron dos categorías que revelan el significado que los estudiantes atribuyen a sus vivencias en el contexto universitario: la universidad que genera sufrimiento y la universidad que brinda crecimiento. Consideraciones finales: Los estudiantes de Licenciatura en Enfermería conciben el contexto universitario como una experiencia ambigua, al mismo tiempo que se percibe a la universidad como generadora de sufrimiento, también es vista como capaz de brindar crecimiento intelectual, sociocultural, afectivo y político

Palabras clave: Estudiantes de enfermería. Salud mental. Universidades. 


\section{INTRODUCTION}

The insertion of the student in the university world makes him experience a series of changes in his life, as well as experiencing a new horizon, an unknown. Surrounded by a series of expectations, fears and uncertainties, the graduating student is faced with a whirlwind of possibilities in the face of new knowledge, new relationships and also responsibilities, commitments, desires, provoking the most varied feelings. Thus, the student builds himself daily, molding himself, reshaping himself, living - each in his own way - what the university has to offer.

In the transition from High School to University Education, the student experiences parallel emotional processes: on the one hand, the mourning for the loss of the peculiarities of childhood and pre-adolescence; and, on the other hand, the responsibilities for one's own life that need to be assumed, when it is necessary to choose a profession when taking the entrance exam, even without being sure that this is the best option ${ }^{(1)}$.

These experiences become even more intense when it comes to undergraduate students in the health area, such as Nursing, as they start to face and deal with dichotomous situations, such as health-disease and life-death, which need to be elaborated so that do not negatively impact their mental health.

With the need to adapt to changes in life and new demands after entering the university, the student can perceive this process as a stressor, which directly impacts in his health ${ }^{(2)}$. Due to practical classes with experiences in a clinical environment during the training process, Undergraduate Nursing students go through stressful situations and report high levels of stress, which is enhanced by several factors, such as: overload in theoretical-practical activities; exhaustive workload of classes, which results in accumulation of academic activities, generating anxiety and anguish; concerns about the labor market; assessment activities; relationship between study, family life and social life; and, relationship with the professor ${ }^{(3-4)}$.

With the advancement of semesters at the university, in addition to the obligation to comply with the curricular hours, most students engage in complementary and extracurricular activities, such as scientific initiation, extension projects and participation in courses, which increases the burden and it can impair quality of life ${ }^{(3)}$. Thus, in a way, the university context imposes a condition of vulnerability to the academic segment for the occurrence of mental disorders, which leads us to believe that aspects related to academic life can impact the mental health of this population ${ }^{(2)}$.
The challenges inherent to the process of personal, social and academic development that young university students experience require maturity and autonomy to face the natural transformations of this life cycle, especially due to the difficulties in meeting their individual, family and community demands ${ }^{(5)}$. The high expectations created in the academic path, ambitions for the professional and personal future, fears and insecurities related to the labor market commonly result in a high prevalence of psycho-affective problems, sometimes unknown, which interferes with the possibility of treatment ${ }^{(6)}$.

When not identified and treated, depressive, anxiety and stress symptoms can increase, resulting in harmful attitudes to the student's life, such as cases of attempted suicide and suicide that have been reported worldwide. Thus, the relevance of the study is to bring to the universe of scientific production a current theme that has been propagated in television and digital media, due to its repercussion in the lives of young university students. It is urgent to talk, debate and propose a new look at the mental health of university students, in the social, political, and psychic spheres.

In this context, the question that guided the present study was outlined: how do Undergraduate Nursing students signify their experience in the university context? And, as the objective of the study: to understand how Undergraduate Nursing students signify their lived experience in the university context.

\section{$\square$ METHOD}

Phenomenological study, excerpt from the doctoral thesis entitled "Perception of undergraduate nursing students about their mental health", of qualitative nature, supported by the philosophical approach of Maurice Merleau-Ponty, more specifically on the experience of the body itself.

To the understanding of the results and discussion, we used the categories presented by Merleau-Ponty about the ambiguity of human perception, which is permeated by two poles, the sensitive and the reflective, as well as the experience of transcendence of the body, of becoming the other myself. The author argues that all perception is ambiguous, as sensitive human nature is intertwined with our reflective consciousness. We are a body in the world and the world in constant interaction, which feels, desires, suffers, thinks, perceives ${ }^{(7-8)}$.

We know that the experiences of students in the university context are experiences of intersubjectivity, of intercorporality, and that, therefore, they are ambiguous. Thus, it is is justified the choice of the Merleau-Pontyan phenomenology 
regarding perception, since the author studies perception as an experience of the body itself, which is an ambiguous experience.

For the author, every perception involves a horizon of the past and a horizon of the future that are updated in a present, and each experience of this perceptual synthesis is dynamic, as each moment corresponds to a new experience, in which the experience of transcendence takes place, the possibility of resignifying their personality and becoming another myself from the experience of temporality ${ }^{(7,9)}$.

This approach is appropriate to the object of study, since we are studying the perception of students of Undergraduate Nursing Course in relation to how they signify the university context. In the case of the university students in the study, we realized that they can transcend, whether in a perspective of suffering, illness, or in the sense of growth, personal and professional development, learning, living together. There may also be an evolution from the condition of suffering to health, or the other way around. There are several transcendences that happen due to these dynamics of perception, because, with each experience that the student has, he develops another perception.

These changes always take place in intersubjectivity, in the intercorporeality between the students themselves, between students and professors, with the intra- and extra-university community. For students to signify this context, they go through several intersubjective and intercorporeal experiences, so that, in this way, they have a multiplicity of perceptions of everyday university life. In other words, the perception we have of an object is based on all the experiences we had or could have of $\mathrm{it}^{(7)}$.

The chosen field of study was the Universidade Estadual de Feira de Santana (UEFS), located in the municipality of Feira de Santana, Bahia, Brazil, which has a Graduate Nursing Course since 1976, and currently offers forty new places each semester. Enrollment for all courses at that university became 100\% through the Unified Selection System (Sistema de Seleção Unificada - Sisu) since the selection process in early 2019.

Students from the Undergraduate Nursing Course of all semesters participated in the study, with the inclusion criteria: being regularly enrolled. Thus, we carried out visits to all classes, separately, to invite them to participate in the research and, on that occasion, we made available a list for interested parties to sign. At that time, we were already scheduling the first meeting with them to resolve possible doubts, as well as reading the Informed Consent Form (ICF) and the Assent Form (AF) in order to obtain signatures on these documents.

To obtain the experiential descriptions, we used Community Therapy (CT) as a methodological strategy and, by mutual agreement, we scheduled the date for the completion of the first round. CT is an Integrative and Complementary Practice in health that consists of a space for speaking and listening in which participants have the opportunity to talk about their anxieties and sufferings and, as the wheel develops, they can find ways to reframe their suffering. For each CT wheel completed, we scheduled the next wheel.

Thus, through CT wheels, we are concerned with obtaining descriptions of the experiences with students of the Undergraduate Nursing Course in an attempt to unveil the phenomena that involve their mental health in the university context. We opted to carry out four thematic CT wheels to facilitate the conduct of $\mathrm{CT}$ and direct it to reach the objective of the study. The meetings of the CT wheels took place from February to April 2019.

Each meeting lasted approximately an hour and a half, during which time, as a researcher/community therapist, we took notes, seeking to synthesize the lines, characterize the participants as to gender, and record the start and end times of the wheel.

All the speeches of the students in the CT wheels were recorded with digital recorders, transcribed in full, so then, we could perform understanding by using the Analytical of Ambiguity technique. Its application involves the following steps: organization of texts resulting from recordings, exhaustive readings of these texts, letting the phenomena stand out, and putting into practice categories that reveal ambiguity ${ }^{(9)}$.

The research fully observed the ethical precepts set out in Resolution No. 466/2012, of the National Health Council/Ministry of Health (Conselho Nacional de Saúde/Ministério da Saúde - CNS/MS)(10). It was approved by the Research Ethics Committee of the Universidade Estadual do Sudoeste da Bahia (CEP/ UESB) under No. 3.092.573 and CAAE 94544618.3.0000.0055. The participants signed the ICF or AF in duplicate, declaring that they are aware of the purpose of the research and authorizing the use of the information provided for scientific purposes. To preserve anonymity, students chose the proper names they wanted to be identified in the survey.

\section{RESULTS}

The participants consisted by 41 students, counting on the four CT wheels performed, and 29 of them participated with verbal expression. From these, 35 students were female, which reflects the profile of Undergraduate Nursing Courses in relation to the greater presence of women, which seems to occur due to the history of the origin of Nursing, which continues to this day.

The students'age ranged from 17 to 42 years. From these, 21 did not choose the Undergraduate Nursing Course as 
their first option, and only one student studied and worked, so that the others, at that time, were exclusively dedicating themselves to their studies. In addition, it is noteworthy that 22 students reported not living with their family, as they came from another municipality to attend graduation.

From the analysis of the experiential descriptions, two categories emerged: the university that generates suffering and the university that provides growth, presented below.

\section{The university that generates suffering}

The repercussions of the insertion of students at the university occur in their lives in the biological/physical, psychological, and socio-family dimensions, as a whole, interconnected.

We realized that in the biological/physical dimension the descriptions corroborate the intimate relationship between the dimensions of our body. So, when one dimension is affected, the other reflects the impact. Students reported changes in the biological dimension but believe that they are closely associated with psychological aspects experienced in the academic context. They emphasize that they feel anxious about practical classes in health services, suffer from pressure from professors and find it difficult to manage the time to be able to carry out intra- and extra-university activities. In this context, changes in appetite and insomnia occur to them.

What really made me feel, in the cocoon, here at the university, was the pressure from the professors [...] I was not anxious, and from university onwards I started to have an anxiety disorder; I started to lose weight. It was starting the internship I lost weight, I stopped eating, I didn't eat[...]. The peak was in the seventh semester [...], I had to take sleeping pills because I was afraid of failing. (Alicia)

The university absorb us, and I suffered a lot from it, because I like to play sports, play ball, do karate. And what Ifeel is that UEFS took that away from me, because since I joined here, I can't have regular karate training, I don't have time for anything else. (lgor)

There are times when I don't want to eat, I can't eat anything; and sometimes, joking, l even eat the walls of the house. (Joana)

After I started the course, what stood out to me the most was that all of this had repercussions on insomnia, to the point of having to take sleeping pills. (Juliana)

Regarding the psychological dimension, the students reveal the coexistence between them regarding the sensitive dimension. They identify the university context as sickening, as responsible for crying, anxiety, crises, felt sadness, stress; that is, they tend to blame the institution for the suffering, especially when referring to pressure from teachers; the competitiveness of colleagues; and excessive workload. However, they veil the socio-anthropological context that envelops other dimensions of their lives.

At the end of lastyear, which, as I am in the 2nd semester, I took semiology, it was like a great pressure on me. My mental health was down there. There were days when, out of nowhere, I started to cry, because I didn't know what to do. I was very locked in the house, I didn't want to go out, precisely because I was feeling very pressured. I still couldn't find an escape from this, a way to try to resolve this pressure of mine. So what I do is stay at home crying, not knowing what to do. At the time, it alleviates, we put pressure on crying, but then it all comes back to the same thing. (Brenda)

My first crisis here at the university was still in the first semester [...] At the beginning we had difficulties, I think it was general, we studied, studied and could not pass; like, I didn't get such good grades [...]; I also studied semiology, which was the second despair, the first contact with the hospital; there were the anxiety crisis, the feeling of incapacity before getting there, the butterflies in my stomach, the fear. (Sofia)

When I started semiology, it was a time of great stress, because I didn't think I would pass; it was a phase where I got really bad emotionally. (Felipe)

I feel very pressured, especially at the end of last year, because of seminars, exams. Out of nowhere I felt like crying, the famous anxiety attack. (Monalisa)

The level of maturity of students when starting university life, with demands for responsibility, discipline and commitment, also interferes in the way they will be able to deal with academic demands. Some find it difficult to understand that adulthood is approaching and that it is necessary to make decisions and take responsibility for own life.

I arrived here when I was 17 years old, and there is a huge demand from the professors, a lot of responsibility for you to deal with at an age when you still don't really know if it's the course you want for your life. And then I started to have an anxiety attack. (Joana)

When addressing the discomfort that feels in the university context, one participant reveals some suffering 
intertwined with the lack of identification with the course, even though it is close to its conclusion, as can be seen in the following description:

What makes me feel bad here at the university are the practices. I don't know if it's because I'm not sure I want to be a nurse, even though I'm already in the ninth semester, I don't know what it is. But in all practices, I don't like it, I don'tenjoy doing it [...]. I don't remember ifl've evergone a semester without crying in practice. (Rute)

The description that follows makes us see that the student, when listening to peers comment on how they suffer at university, tends to repeat and generalize the discourse. Based on the Merleau-Pontyan ontology, the body constitutes porous flesh and, as such, emits and receives information that makes it experience the other myself, whether in the sense of satisfaction or in dissatisfaction and suffering(7).

I think that, in the university context, the worst moment for us is the pressure that we suffer here, regardless of the semester, and the tendency is always to get worse, that's what they say to us and we incorporate it. As the semester goes on, everyone tends to get more nervous, more stressed. It's almost a collective outbreak, you see someone stressed in your class, you get stressed too [...]. I had a lot of psychological disorders because of the two disciplines I had to give up, because I thought I was incapable. (Renata)

In this description, we perceive the universality of feeling among students, coexistence, that is, what one lives seems to transcend the other ${ }^{(7)}$. Regarding the experiences of psychic suffering, students point out that, as one expresses feelings of anxiety and impotence, the similar is affected and, little by little, everyone in the class tends to experience similar sensations. However, we also note in the description the ambiguity between feeling and thinking. While the participant reveals sharing the sensitive nature with peers, she recognizes that the feeling of impotence is not in the other, but in herself.

Regarding the socio-family dimension, even with the expansion of the Brazilian higher education system, the insertion of the student in the university may require the removal of the family, especially if there is a need to change the city of origin, when it does not have a public university or the desired degree course. This change can negatively impact both the student's mental health and academic performance, since, with the physical distance from the family, social support, and support for decision-making decreases. Furthermore, the rupture of family dynamics in an adolescent's life and their insertion in an unknown context can lead them to feel insecure to build new relationships and, consequently, to isolation.

For me, without a doubt, what makes me feel most like a cocoon in university life is the distance from the family. I'm very attached to my family and when I spend a lot of time away, it reverberates in my emotions, even in my graduation performance. When I came to university I lived for 2 and a half years alone [...] so sometimes you feel too lonely, and you feel sad. Thus, the first impulse is not for you to go contact other people, but for you to stay quiet, to become more reclusive. (Felipe)

Some students, like Felipe, are able to perceive that the experiences of suffering in the university context are not generated exclusively by events concerning the academy, but by external factors such as distance from the family. However, there are those who really blame the university for the discomfort experienced, as can be seen in the following description:

I always talk about the workload at the university [...] it seems that the university creates a bubble and you have to stay inside it [...] Competitiveness is an unnecessary suffering for everyone, and I think that this competitiveness is built inside the university. (Rosa)

The need for exclusive dedication to the university was highlighted in some descriptions. Students show commitment of all their time to fulfilling academic demands and that they have no opportunity to dedicate themselves to family, leisure, emotional relationships, a healthier lifestyle, and even work activities:

I didn't see my boyfriend for two weeks, and I was just studying. I came home, studied, studied, studied, I didn't want to see anyone. (Alicia)

Sometimes I want to do something and the workload ends up preventing me, because when the end of the week comes, I have to take care of the subjects, the works, the tests that you will have to take. So, we have classes in the morning and afternoon, arriving at night dead tired and you have to study. And then sometimes I miss time for myself. (Ana Helena)

My main cocoon during this entire period of university was depending financially on my parents [...] it's the worst thing, it's what made me think about giving up college. (Juliana) 


\section{The university that provides growth}

Entering the university and dedication to the university world require a break with the previous routine and the construction of a new routine, a new lifestyle, because, in this context, other relationships and forms of coexistence are produced, as well as other behavioral demands. Despite such changes occurring in the lives of students, the university opens doors for them to build another myself.

Although the descriptions reveal the discourse of suffering related to excessive academic demands, competitiveness, the difficult relationship between professor and student due to the pressure imposed, they also show the recognition of personal growth, autonomy and independence, acquired from immersion in the university environment.

Forme the suffering provided maturity, because lentered younger than the average here. So, for me to find myself was a little complicated, but it made me mature. (Igor) I think it was a necessary suffering the fact that I arrived and I felt very lonely, I didn't have anyone [...], today I think it's important, becausel could open my mind, have more autonomy, to be more independent. (Samanta)

l evolved as a person by being alone here, knowing how to cook my own food, which I didn't know, washing my clothes, getting by. Because I always depended a lot on my mother. (Rosa)

Being well alone was something that I discovered experiencing the university, when I came here, during the period I lived alone, mainly. (Felipe)

One good thing the university brought me was maturity and resilience. (Sofia)

Entering the university, starting to deal with situations that are completely different from those previously experienced in the school and family environment, provide the transcendence for maturation, development as a human being, encouragement to exercise citizenship, ability to become resilient, all of this makes the student experience the"I can"experience. Next, we notice the perceptive exercise under the figure-ground look, when the student looks at the difficulty, at the challenge and perceives the possibility of becoming another myself.

Regarding the disciplines, they are really difficult, but the more the discipline is difficult and in the end I manage to do well, I like it, because it challenges me. Even being suffered, in the end when I manage to overcome it, for me it has a very big return. (Juliana)
In addition, the experience of the university context in a broader dimension, beyond the Undergraduate Nursing Course, such as, for example, through the participation and composition of the student movement, was pointed out by one participant as an opportunity for transcendence for personal growth, relational, dialogic and political. Thus, the social history she has been building at the university will make her different from other students who have not experienced the movement.

I see how a very positive point for me is being inserted into the student movement, which I like, it's something that strengthens me, and when I'm inside something that involves the student movement, it makes me feel like a butterfly inside the university space. And it's also something that somehow improves and helps me in terms of mental health. (Marina)

The university also appears as a protective environment for students who are in the final stretch of the course, in view of the insecurity regarding the insertion in the labor market. Thus, the student lives the ambiguity. On the one hand, it suffers from the pressures and overloads of the university context, on the other hand, it wants to remain in it, as the world outside it is uncertain.

I think the cocoon, while imprisoning, also protects. So, I see that the university, today, for me, represents a protection in this sense. Because I'm already leaving, there's only one semester left, and when I get out of this cocoon? (Rute)

\section{口DISCUSSION}

As this is a phenomenological study, whose theoretical matrix is about the suspension of naturalized discourses, through the understanding of text and context, figure and ground, the discussion of the results is supported by the theoretical-philosophical framework that guided the entire construction of the research being the Maurice Merleau-Ponty's approach to perception.

The author approaches human perception from what he considers as own body. For the philosopher, the body corresponds to temporality, which consists of the perceptual synthesis, that is, in the act of perceiving, the person updates in the present a horizon of the past and another of the future, always in a creative way. The self means the person's ability to transcend himself, in the sense of changing the self, through the flow of time (temporality). Thus, Merleau-Ponty describes 
the own body as intercorporeality, considering that no human being lives for himself, but in an intersubjective way ${ }^{(7)}$.

Thus, based on the Merleau-Pontyan language, the discussion of the study results on the perception of Undergraduate Nursing students in relation to their mental health is based on the intertwining of what are shown as ambiguities in the experiential descriptions produced with them, and the ontology of the own body. Such a proposal is completely opposed to the determinism of the naturalistic sciences, according to which things already are in themselves.

In this perspective, the university seen as "in itself" by students in the context of the theme in question points towards the consistency of the choice of the theoretical framework of Merleau-Ponty to support the study, since the author's approach is opposed to all objectivist discourse. Thus, we understand that the intersubjectivity established with the participants resulted in the description of their experiences in the university context, and not in the explanation of situations that they point out as generators of suffering, nor its manifestations, since every explanation is already a naturalized discourse.

Therefore, in our study, we seek to deconstruct theses, discourses embedded in the sociocultural environment that are thoughtlessly repeated as if they were absolute truths, such as the idea that "the university gets sick". We then proposed to go beyond the idea of "in itself" and share a new way of thinking about the theme, starting from the understanding that every experience is ambiguous, since it involves intersubjectivity.

Thanks to this ambiguity of human perception, we can develop a figure and depth look and see, for example, that the academic demands and the conflicting relationships emerging from the university environment are profiles of a totality that escapes any attempt to apprehend it completely. It is about the reflexivity of each student, which makes, at the same time, similar to the others of his species, and distinct by his sociocultural experience.

Merleau-Ponty defends that all knowledge is produced in the intercorporeality, through a dialogical relationship. Therefore, each communicative act is intercorporeal and reveals a new profile in the dynamics of perception ${ }^{(7)}$. Therefore, the experiences of Nursing students unveiled in the descriptions were shown to us not as defined categories or finished conceptions, but as profiles of ambiguities concerning their own body.

The university context has been the target of criticism on the world stage, for the way its community has suffered when experiencing it. However, we perceive a naturalized guilt in relation to the university, which inscribes it as the main responsible for what is suffered. In this sense, students see the university as something in itself, as the villain of all the discomfort and suffering they experience in any of the physical/biological, psychological and socio-family dimensions. It is an objectivist look, as if they were outside the university, and not as someone who is part of it, being part of it.

Study participants revealed that the academic routine negatively affects their mental health due to the changes that occur in their routine and lifestyle in the face of the institution's demands. As a result of these changes, they experience, for example, sadness, crying episodes, lack of appetite, insomnia, isolation, anxiety attacks, among other manifestations. In light of Merleau-Pontyan thinking, we understand that blaming the university context for these events, ignoring the reflexivity of each student, constitutes an objectivist attitude, that is, it focuses on the figure (a profile) and loses sight of the ground (the totality from which the profile emerges).

The change in the sleep pattern, reported as a reduction in its quantity, was frequently mentioned by the participants. This fact corroborates a study carried out with other students in the health area, whose results and discussion support the strong association between decreased sleep and the occurrence of anxiety, which affects the interest in daily activities and can generate other health problems $s^{(11)}$.

Although students blame the university for affecting their mental health, the literature points out other aspects that make them more vulnerable to the situations of suffering they describe, such as socioeconomic and family situations ${ }^{(12)}$. Therefore, the university itself is not the villain of suffering. It presents profiles of a universe of factors that can contribute to the expression of suffering. We understand that the student, when entering the university and starting to share experiences that lead them to see it as "in itself", they start to project on it the anguish and suffering arising from other experiences.

In the early semesters, there are difficulties in adapting, managing time, understanding the new dynamics of life, establishing and building new bonds, in addition to the demands of a lot of dedication to studies, disparity between obligation and leisure and fear of not being able to achieve desired results throughout the Course. Furthermore, the student can also experience conflicting relationships with professors, feeling pressured by them ${ }^{(13)}$.

The descriptions also revealed that students experience two types of pressure. At the same time that they talk about pressure from professors, they report suffering self-pressure, a pressure exerted by themselves on themselves. The latter can occur even more intensely in the two semesters that precede the conclusion of the undergraduate Nursing course, in which they carry out internships with indirect supervision 
from the professors, as they feel like professionals from the Health Services and, although they have the support and the necessary guidelines for internships, need to have more autonomy, responsibility and decision-making than those of previous semesters ${ }^{(14)}$.

In this sense, in many situations, the student finds himself alone. Thus, on the one hand, a feeling of self-sufficiency may emerge, as they start to perform actions without the presence of the professor. On the other hand, he might feel helpless ${ }^{(14)}$ and anxious, and present episodes of crying and despair at the internship environments.

In this way, we corroborate the Merleau-Pontyan ontology about the dynamics of being and, thus, we realize that the ambiguities experienced by Nursing students in the university context occur in the constant intertwining of feeling and thinking ${ }^{(8)}$, dimensions of human nature within the scope of perception. The descriptions show that from the first semesters of the course, students are affected, both by their unique intuitive response to the new reality to which they are submitted, and by the incorporation of deterministic speeches from colleagues, such as the thesis that anxiety and suffering experienced at the beginning of the course tend to intensify throughout the academic trajectory.

By incorporating this thesis, students start to propagate the idea that the university makes them ill. Therefore, our study echoes Merleau-Ponty's criticism to the objectivism and determinism peculiar to the natural sciences ${ }^{(7)}$, as it consisted in suspending the theses that caught our eyes during the attentive reading of the participants'descriptions, and in recognizing in our own body the ambiguities ${ }^{(8)}$, are also found in the other and in the sociocultural world in which we are in.

With this understanding, we are not ignoring the fact that the university context can favor the occurrence of suffering and mental illness, as our body, as a perceptive experience, constitutes porous flesh ${ }^{(8)}$ and, as such, affects and is affected in intersubjectivity. What we refute is the objectivist assertion found in the literature that all phases of graduation and the relationships produced at the university are configured as creative or pathogenic processes for the student, interfering in the educational, social and psychological aspects ${ }^{(15)}$, without, however, problematize the entire socio-family environment involved in the lives of students.

Every human being experiences psychic suffering during life, which can evolve and express itself in relationships ${ }^{(16)}$. However, the way in which suffering occurs in life will depend on the reflexivity of each person, allowing them to experience different meanings, since suffering is associated with the experience of one's own body based on temporality.
The descriptions of the participants corroborate what is seen in the literature on the subject, that the Nursing student generally dedicates all their time to academic activities and, as a result, can develop suffering and illness in its entirety, which involves the physical, psychic and sociocultural dimensions ${ }^{(11,13)}$. However, once again, in the light of Merleau-Ponty, we refute this objectivist perspective, as it is based on establishing cause-and-effect relationships in complex situations such as suffering.

A study points out that "the contemporary subject has a feeling of impotence in the face of high performance requirements and, being free, can invest in their tendency to create life and love, as well as in the destructive ones, being able to annihilate what he himself built"(16). For Merleau-Ponty, regardless of the circumstances experienced, whether stress, emotional tension, discomfort, pain, suffering, or satisfaction, pleasure, health and life, there is always the possibility of transcendence, the person can become another. Thus, in a way, the experiences of Nursing university students, whether in a context of protection or vulnerability, result in personal and social growth.

In this context, the study shows that the elaboration of university experiences occurs differently in each student, depending on numerous unique factors, with greater or lesser psychological vulnerability, ease or difficulty for interpersonal relationships, use of coping strategies and adaptive mechanisms ${ }^{(17)}$

The student who transcended to a situation of suffering can produce resilience and evolve to a health profile, of quality of life. Based on Merleau-Ponty's ontology, we understand that suffering produced and experienced in the coincident period of student immersion in the university becomes a horizon of the past, which the body, as a power, made possible the experience of "I can", by ability to become another myself through temporality ${ }^{(7)}$.

The way each human being will manage to deal with academic demands, whether it goes beyond annihilation, illness, or intellectual and personal growth, will depend on their socio-anthropological universe. The literature points out, for example, that religious practice is a protective factor for the subject, helping them to deal with suffering, as well as interpersonal bonds can exert a strong influence on the person's behavior, as in cases of suicidal ideation ${ }^{(5)}$. Furthermore, there is a greater correlation between the prevalence of depression in students and unsatisfactory relationships with family, friends, colleagues and professors ${ }^{(11)}$.

The university period has a significant importance in the life of the adolescent/young adult, as it is marked by many new experiences, challenges and life events. During 
this transition period, students acquire more independence and freedom, experience changes in social systems, acquire relevant life skills, in addition to the diploma, which enables them to have a better future(18).

Thus, despite the experiential descriptions reveal suffering, the university world is also marked by growth, from the perspective of both professional and human training. In addition to intellectual development and acquisition of a background of knowledge, the subject also develops skills for interpersonal relationships, for communication, acquires freedom, autonomy, independence and a sense of responsibility.

However, the young student, seen as a being in transition, going through a process of preparation for adult life, experiences conflicts of insecurity and difficulty in making decisions. With increasingly unstable social structures, this young person can remain in permanent tension between the present and the future. At the same time that he has a desire for independence, he has difficulty in freeing himself from the bonds of dependence, due to the fear of facing adulthood.

This ambiguity is shown in the descriptions of the participants in our study when they refer to the university as a space of social security, protection, but also insecurity, as they feel fear and concern about the possible challenges they will face to enter the labor market after completion of the Course. These students unveil a not knowing themselves through the movement of transcendence of perceptive experiences.

Given the descriptions in which Nursing students reveal complaints of suffering, which they attribute to insertion in the university context, regardless of whether the arguments constitute an objectivist view or not, in the sense that they blame the institution as a generator of factors that make them ill, we perceive the need for the university to make efforts to plan and implement care strategies, both for health promotion and intervention to manage suffering in the academic environment, aiming at the well-being of students inside and outside the university environment.

\section{FINAL CONSIDERATIONS}

The figure-ground look, characteristic of Merleau-Ponty's ontology, allowed us to understand how Undergraduate Nursing students signify the university context. We noticed in the descriptions that they see the university as one in itself, as a villain responsible for the suffering they experience in their academic trajectory. They reproduce the objectivist discourse of blaming the university, seeing it as an outsider, not as someone who actually lives it; they focus the gaze on a profile and veil the totality from which it emerges.

The study shows that university demands require changes in the students'life routines, which, added to the uniqueness of each one and the socio-family and cultural aspects, can affect their mental health. However, the insertion in the academic environment and the sharing of experiences that lead them to see it as a villain make them project on it all the anxieties and sufferings produced by other experiences.

In this sense, students reported that, since the first semesters of the course, their health is affected in an integral way, involving physical, social, emotional, and cultural dimensions. They also highlighted that the way in which suffering happens in each one's life, as well as the way they manage to deal with it, depend on their socio-anthropological universe. Thus, it is not possible to establish a cause-and-effect relationship, due to the complexity that involves situations of suffering.

Based on Merleau-Pontyan thinking, we understand that the ambiguities experienced by students in the university context occur in the constant intertwining of feeling and thinking. At the same time that the university is identified as a generator of suffering, it is also seen as capable of providing intellectual, sociocultural, affective and political growth. Therefore, regardless of the circumstances experienced, whether of suffering or satisfaction and pleasure, the student can always resignify his life and become another myself.

We believe that the study can contribute to having a different look at university students, especially those in the undergraduate Nursing course, due to its specificity, which involves the student's life in the physical, psychological, socio-family, and cultural aspects. Therefore, it is necessary for the faculty to reflect on how to stimulate and produce knowledge, seeking to build healthy relationships with students and promote mental health. We also hope that the study can mobilize social and political actors to make efforts aimed at supporting the mental health demands of the academic community, including the formulation and implementation of mental health care policies and the reduction of suffering.

We point out as limitations of the study the fact that we do not have a consolidated mental health support network available at the university, so that it is possible to make referrals of some needs unveiled from the CT wheels. Furthermore, due to the carrying out of thematic wheels, aimed at achieving the objective of the study, possibly many other demands were suppressed. Thus, we understand that there is a lot to unveil from what is experienced in the university world. 


\section{REFERENCES}

1. Borine RCC,Wanderley KS, BassittDP. Relação entre a qualidade de vida e o estresse em acadêmicos da área da saúde. Estudos Interdisc Psicol. 2015;6(1):100-18. doi: https://doi.org/10.5433/2236-6407.2015v6n1p100

2. Ariño DO, Bardagi MP. Relação entre fatores acadêmicos e a saúde mental de estudantes universitários. Psicol Pesqui. 2018 [cited 2019 Jul 17];12(3):44-52. Available from: http://pepsic.bvsalud.org/pdf/psipesq/v12n3/05.pdf

3. Rodrigues EOL, Marques DA, Lopes Neto D, Montesinos MJL, Oliveira ASA. Stressful situations and factors in students of nursing in clinical practice. Invest Educ Enferm. 2016;34(1):211-20. doi: https://doi.org/10.17533/udea.iee.v34n1a23

4. Sailer GC, Sanches GF, Vale BC, Pereira SS, Preto VA, Almeida CC. Burnout syndrome among graduates of undergraduate nursing course. J Nurs UFPE on line. 2017 [cited 2019 Jul 20];11(1):31-9. Available from: https://periodicos.ufpe.br/revistas/ revistaenfermagem/article/view/11875/14326

5. Santos HGB, Marcon SR, Espinosa MM, Baptista MN, Paulo PMC. Factors associated with suicidal ideation among university students. Rev Latino-Am Enfermagem. 2017;25:e2878. doi: https://doi.org/10.1590/1518-8345.1592.2878

6. Padovani RC, Neufeld CB, Maltoni J, Barbosa LNF, Souza WF, Cavalcanti HAF, et al. Vulnerabilidade e bem-estar psicológicos do estudante universitário. Rev Bras Ter Cogn. 2014;10(1):2-10. doi: http://doi.org/10.5935/1808-5687.20140002

7. Merleau-Ponty M. Fenomenologia da percepção. 4. ed. São Paulo: Martins Fontes; 2015.

8. Merleau-Ponty M. 0 visível e o invisível. São Paulo: Perspectiva; 2014.

9. Sena ELS, Gonçalves LHT, Müller-Granzotto MJ, Carvalho PAL, Reis HFT. Analítica da ambiguidade: estratégia metódica para a pesquisa fenomenológica em saúde. Rev Gaúcha Enferm. 2010;31(4):769-75. doi: https://doi.org/10.1590/ S1983-14472010000400022

10. Ministério da Saúde (BR), Conselho Nacional de Saúde. Resolução nº 466, de 12 de dezembro de 2012. Aprova diretrizes e normas regulamentadoras de pesquisas envolvendo seres humanos. Diário Oficial União. 2013 jun 13 [cited 2020 Sep 14];150(112Seção 1):59-62. Available from: https://pesquisa.in.gov.br/imprensa/jsp/ visualiza/index.jsp?data=13/06/2013\&jornal=1\&pagina=59\&totalArquivos=140
11. Leão AM, Gomes IP, Ferreira MJM, Cavalcanti LPG. Prevalência e fatores associados à depressão e ansiedade entre estudantes universitários da área da saúde de um grande centro urbano do nordeste do Brasil. Rev Bras Educ Med. 2018;42(4):55-65. doi: https://doi.org/10.1590/1981-52712015v42n4rb20180092

12. Labrague LJ, McEnroe-Petitte DM, Al Amri M, Fronda DC, Obeidat AA. An integrative review on coping skills in nursing students: implications for policymaking. Int Nurs Rev. 2018;65(2):279-91. doi: https://doi.org/10.1111/ inr. 12393

13. Silva RM, Costa ALS, Mussi FC, Lopes VC, Batista KM, Santos OP. Health alterations in nursing students after a year from admission to the undergraduate course. Rev Esc Enferm USP. 2019;53:e03450. doi: https://doi.org/10.1590/ s1980-220x2018008103450

14. Restelatto MTR, Dallacosta FM. Vivências do acadêmico de enfermagem durante o estágio com supervisão indireta. Enferm Foco. 2018;9(4):34-8. doi: https://doi. org/10.21675/2357-707X.2018.v9.n4.1156

15. Castro VR. Reflexões sobre a saúde mental do estudante universitário: estudo empirico com estudantes de uma instituição pública de ensino superior. Rev Gestão Foco. 2017 [cited 2019 Nov 11];9:380-401. Available from: http://portal.unisepe. com.br/unifia/wp-content/uploads/sites/10001/2018/06/043_saude_mental. pdf

16. Macêdo S. Sofrimento psíquico e cuidado com universitários: reflexões e intervenções fenomenológicas. Ecos. 2018 [cited 2019 Nov 11];8(2):26577. Available from: http://www.periodicoshumanas.uff.br/ecos/article/ view/2844/1566

17. Nogueira-Martins LA, Nogueira-Martins MCF. Saúde mental e qualidade de vida de estudantes universitários. Rev Psi Divers Saúde. 2018;7(3):334-7. doi: http:// doi.org/10.17267/2317-3394rpds.v7i3.2086

18. Stoliker BE, Lafreniere KD. The influence of perceived stress, loneliness, and learning burnout on university students' educational experience. Coll Student J. 2015 [cited 2019 0ct 14];49(1):146-60. Available from: https://www. researchgate.net/publication/282817514_The_Influence_of_Perceived_ Stress_Loneliness_and_Learning_Burnout_on_University_Students'_ Educational_Experience 


\section{- Authorship contribution:}

Conceptualization - Luma Costa Pereira Peixoto, Edite Lago da Silva Sena.

Data curation - Luma Costa Pereira Peixoto, Edite Lago da Silva Sena.

Formal analysis - Luma Costa Pereira Peixoto, Edite Lago da Silva Sena.

Funding acquisition - Luma Costa Pereira Peixoto. Investigation - Luma Costa Pereira Peixoto, Edite Lago da Silva Sena.

Methodology - Luma Costa Pereira Peixoto, Patrícia Anjos Lima de Carvalho, Edite Lago da Silva Sena.

Project administration - Luma Costa Pereira Peixoto, Edite Lago da Silva Sena.

Supervision - Edite Lago da Silva Sena.

Writing-original draft - Luma Costa Pereira Peixoto, Edite Lago da Silva Sena.

Writing-review \& editing - Luma Costa Pereira Peixoto, Evangelia Kotzias Atherino dos Santos, Luana Machado Andrade, Patrícia Anjos Lima de Carvalho, Edite Lago da Silva Sena.

The authors declare that there is no conflict of interest.

\section{- Corresponding author:}

Luma Costa Pereira Peixoto

Email: lumacosta88@hotmail.com

Associate editor:

Cíntia Nas

Maria da Graça Oliveira Crossetti 